- Gi respons på artikler gjennom artiklenes kommentarfelt på tidsskriftet.no.

Innleggene publiseres fortløpende på Tidsskriftets nettside og et utvalg

av innleggene publiseres også i papirutgaven i spalten «Brev til redaktøren».

Redaksjonen forbeholder seg retten til å foreta redaksjonelle endringer.

Forfattere av vitenskapelige artikler har tilsvarsrett, jf. Vancouver-gruppens regler.

Medisinsk redaktør K. Slagstads leder Psykiatriens indre konflikter eksponert $i$ Tidsskriftet nr. 6/2017 har utløst debatt. Vi bringer her noen av innleggene, resten finner du på våre nettsider.

\section{Re: Psykiatriens indre konflikter eksponert}

Det er uvanlig at tidsskriftets redaktør bevilger seg selv spalteplass til å fremme egne synspunkter på det historiske, filosofiske og vitenskapelige grunnlaget for et fagområde, slik K. Slagstad gjør i Tidsskriftet nr. 6/2017 (1). Velger man å gjøre det, er det i så tilfelle viktig å være forsiktig med for kategoriske påstander om kunnskapsstatus, særlig når man bruker slike påstander som grunnlag for å forklare at fagpersoner har ulike syn på behandlingstilbud.

Når Slagstad anfører at vi har begrenset kunnskap om årsaker til psykiske lidelser, kan det for noen leses som man har mer kunnskap om årsaken til somatiske sykdommer som f.eks. kreft, migrene eller irritabel tarm. Det stemmer ikke slik jeg kjenner kunnskapsfronten. Kunnskapen om genetiske, fysiologiske og biokjemiske endringer ved alvorlige psykiske lidelser som bipolare lidelser og schizofreni er fullt på høyde med hva vi vet om mange såkalte somatiske sykdommer. Ved bipolare lidelser (2) og schizofreni (3) vet vi f.eks. at det er tale om systemsykdommer i betydningen av at det ved slike sykdommer eller lidelser er endringer i en rekke ulike kroppsfunksjoner og organer, ikke bare i sentralnervesystemet. Det innebærer bl.a. forøket forekomst av en rekke legemlige sykdommer som stoffskifte-, hjerte- og kar og lungesykdommer.

I motsetning til Slagstad mener jeg også at dagens kunnskap om alvorlige psykiske lidelser har hatt - og har fortsatt - betydning for utviklingen av nye diagnostiske metoder samtidig som kunnskapen har medført øket forståelse for betydningen av psykososiale behandlingstiltak på samme måte som kunnskapsutvikling innen somatisk medisin har vist betydningen av tillegg av psykososiale behandlings- og rehabiliteringstiltak for optimalt behandlingsresultat.

Diskusjonen om og i hvilken grad man skal ha egne avdelinger for medisinfri behandling av alvorlige psykiske lidelser som bipolare lidelser og schizofreni handler derfor etter mitt syn ikke nødvendigvis om ulikt vitenskapssyn, men kanskje mer om hvilke etiske implikasjoner man trekker av dagens forskningsbaserte kunnskap med tanke på behandlingstilbud. Jeg tror at en pro et contra-debatt basert på slike premisser vil være mer fruktbar enn å trekke hele kunnskapsgrunnlaget til et fagområde i tvil som en premiss for debatten.

\section{Ulrik F. Malt \\ u.f.malt@medisin.uio.no}

Ulrik F. Malt (f. 1946) er professor emeritus og overlege ved Oslo universitetssykehus

Oppgitte interessekonflikter: Forfatter forsker på nevrobiologiske aspekter ved bipolare lidelser og har tidligere forsket på bruk av legemidler så vel som psykososiale intervensjoner i behandling av depresjoner og schizofreni. I 2016 mottok han honorar for forelesninger om psykofarmakologi fra Norsk Psykiatrisk Forening samt fra svenske METIS-kurs i C-L psykofarmakologi og tyske Berlin-kurs i C-L psykofarmakologi - ikkekommersielle kursarrangører. I 2016 mottok han også honorar fra Lundbeck Norge for å forelese om psykiatriske emner for leger innenfor det psykiske helsevern.

\section{Litteratur}

1. Slagstad K. Psykiatriens indre konflikter eksponert. Tidsskr Nor Legeforen 2017: 137: 421

2. Muneer A. Staging models in bipolar disorder: a systematic review of the literature. Clin Psychopharmacol Neurosci 2016; 14: 117-30.
3. Malt EA, Juhasz K, Malt UF et al. A role for the transcription factor Nk2 homeobox 1 in schizophrenia: convergent evidence from animal and human studies. Front Behav Neurosci 2016; 10: 59.

\section{Re: Psykiatriens indre konflikter eksponert}

Vi ble invitert til å skrive en kommentarartikkel i forbindelse med en pågående debatt om medikamentfrie sykehusposter for psykosepasienter, hvor vi redegjorde for kunnskapsgrunnlaget og fremsatte vårt syn (1). Til vår overraskelse har samme redaktør i samme nummer av Tidsskriftet en etter vår oppfatning polemisk leder hvor han fremsetter et motsatt syn. Vi håper ikke at dette er i tråd med offisiell politikk fra Tidsskriftet. I tillegg virker redaktøren å mangle kunnskap på feltet, og fremsetter påstander som er lite gjennomtenkte og prinsipielt diskutable for en redaktør i et medisinsk tidsskrift.

Helsevesenet i Norge skal følge nasjonale retningslinjer med mindre disse er åpenbart utdaterte. Disse retningslinjene baseres på prosesser som inkluderer brukere og har prosedyrer for behandling av tema hvor det er lite evidens. Redaktørens innlegg kan fremstå som han mener at vi ikke skal følge slike retningslinjer, og at faglig innhold $i$ helsevesenet skal bestemmes av politisk ledelse og pressgrupper. Vi mener at det først må igangsettes forskning på den aktuelle problemstilling for å sjekke effekt, før det settes i verk nye, udokumenterte tiltak. Redaktøren fremmer et motsatt syn.

Vi mener det er nok kunnskap i psykiatrien til å drive evidensbasert på flere felt. Redaktøren fremsetter påstander om mangel på kunnskap i psykiatrien, mye begrunnet ut fra filosofiske betraktninger og personlige holdninger. Tidsskriftets redaktør fremstår støttende til at innføring av flere tiltak som ikke er kunnskapsbasert vil hjelpe et fag med kunnskapsmangel. Det er meget betenkelig.

I lederen kommer det også frem holdninger og verdivurderinger som er uheldige. Innholdet kan forstås som om de som støtter kunnskapsbasert behandling i psykiatrien er mindre ydmyke, dvs. at de ikke er på pasientenes parti. Det er nettopp de alvorligst syke vi er spesielt opptatt av, og de har krav på det som til enhver tid er den beste evidensbaserte behandling.

Vi er klare på at psykofarmaka gir bivirkninger, at det er mye feil bruk av medikamenter til pasienter med psykiske lidelser generelt, og det finnes åpenbare forbedringsmuligheter. I tillegg er det ingen tvil om at pasienten selv skal bestemme hva de vil motta av behandling, inklusive medikamenter. I det ordinære helsevesenet finnes det tilbud til personer med psykoselidelser som ikke bruker antipsykotika. Men basert på kunnskap i feltet er dette ikke noe som vi generelt vil anbefale. For de aller fleste pasienter med psykoselidelse er det snakk om både medikamenter (i lave doser på riktig tidspunkt og med riktig varighet) og psykososial behandling.

Dogmer og kunnskapsløs behandling tilhører fortiden i psykiatrifeltet. Derfor er det betenkelig at det dukker opp i en lederartikkel av medisinsk redaktør i Tidsskriftet.

\section{Jan Ivar Røssberg \\ j.i.rossberg@medisin.uio.no \\ Ole A. Andreassen}

Stein Opjordsmoen IIner

Jan Ivar Røssberg (f. 1966) er professor ved Universitetet i Oslo. Ingen oppgitte interessekonflikter.

Ole A. Andreassen (f. 1966) er professor i psykiatri ved Norsk senter for forskning på mentale lidelser (Norment), Universitetet i Oslo.

Oppgitte interessekonflikter: Forelesningshonorar fra Lundbeck. 
Stein Opjordsmoen Ilner (f. 1942) er professor emeritus ved Universitetet i Oslo

Oppgitte interessekonflikter: Mottatt honorar fra Lundbeck, Otsuka og Sunovion.

\section{Litteratur}

1. Røssberg JI, Andreassen OA, Ilner SO. Medisinfrie sykehusposter - et kunnskapsløst tiltak. Tidsskr Nor Legeforen 2017; 137: 426-7.

\section{Sjefredaktør A. Brean svarer:}

En av Tidsskriftets medisinske redaktører, Ketil Slagstad, har skrevet en lederartikkel i Tidsskriftet nr. 6/2017. Den har falt psykiatriprofessorene Røssberg, Andreassen og Opjordsmoen Ilner tungt for brystet. De fremsetter en rekke alvorlige påstander om medisinsk redaktør Slagstad. Det er forstemmende at tre meritterte professorer i psykiatri ikke en gang gjør forsøk på å forankre påstandene i teksten de kritiserer.

Forfatterne reagerer for det første på saksgang og at Slagstad polemiserer mot deres innlegg. Leser man Slagstads leder, vil man se at Røssberg og medforfatteres innlegg kun nevnes for å rammesette diskusjonen. For øvrig nevnes ikke deres innlegg i det hele tatt.

Forfatterne postulerer at Slagstad «fremsetter påstander som er lite gjennomtenkte og prinsipielt diskutable for en redaktør i et medisinsk tidsskrift», men unnlater å nevne hvilke, slik at dette blir hengende i luften som en løs personkarakteristikk. En slik debatteknikk er kanskje effektiv, men ikke særlig etterrettelig. Forfatterne hevder at Slagstads innlegg kan leses som at vi ikke skal følge retningslinjer innen behandling av psykiske lidelser, og at «faglig innhold i helsevesenet skal bestemmes av politisk ledelse og pressgrupper». Dette er alvorlige påstander som ikke kan gjenfinnes i Slagstads innlegg. Forfatterne hevder at Slagstad mener tiltak, som medisinfrie tilbud, kan igangsettes uten dokumentert effekt. Dette er en fordreining av hva han har skrevet, nemlig at vi mangler kunnskap på feltet, og at «samfunnet ikke kan betale for behandling som ikke har effekt». Snarere etterlyser han, nå som medisinfrie avdelinger opprettes, at dette burde ha «vært fulgt av en rekke forskningsprosjekter.» Forfatterne oppfatter det som «meget betenkelig» hva de beskriver som at Slagstad mener at mangel på kunnskap i psykiatrien skal avhjelpes av å innføre flere tiltak som ikke er kunnskapsbasert. Heller ikke her har forfatterne støtte i teksten: Slagstad skriver eksplisitt at «behandling må dokumenteres» og viser til historiske eksempler på at å innføre behandling uten kunnskapsmessig støtte ikke er en farbar vei. Likevel forsøker han å problematisere hva vi bør gjøre når vi mangler kunnskapsmessig støtte for et tiltak som pasienter ønsker. Forfatterne påstår at Slagstad har insinuert at «de som støtter kunnskapsbasert behandling i psykiatrien er mindre ydmyke, dvs. at de ikke er på pasientenes parti.» Dette er en grov påstand, særlig tatt i betraktning at det ikke er noe belegg for den i Slagstads tekst.

Medisin er debatt. Men debatt må kunne føres på et saklig og etterrettelig nivå. Løse personkarakteristikker og manglende konkretisering av grove påstander mot andre fremmer ikke konstruktiv debatt.

Are Brean

Are.Brean@tidsskriftet.no

Are Brean (f. 1965) er spesialist i nevrologi, ph.d. og sjefredaktør i Tidsskriftet.

Ingen oppgitte interessekonflikter

\section{K. Slagstad svarer:}

Min lederartikkel har ført til debatt. Det er imidlertid viktig at diskusjonen ikke ledes vekk fra sakens kjerne - etter mitt syn om vi med dagens kunnskap om behandling av psykiske lidelser likevel kan forsvare å opprette et medisinfritt behandlingsalternativ for pasienter med alvorlig psykisk lidelse. Jeg har ingen sterke meninger om et medisinfritt behandlingsalternativ på egne sykehusavdelinger er en god idé, men jeg har sagt at vi bør lytte til pasientene. Og jeg har reist spørsmålet om vi vet nok om hva som er viktig for dem. Jeg følger Malt $\mathrm{i}$ hans forslag om å se på argumenter for og imot innføring av medisinfrie behandlingsalternativ. Slik jeg skriver i lederartikkelen, kan samfunnet ikke betale for tiltak som ikke har effekt, og at det er et åpenbart gode i moderne medisin at behandling må kunne dokumenteres.

For det første skulle jeg ønske at vi i kunne diskutere om vi vet nok om hva kravet om medisinfritt behandlingsalternativ springer ut av. Vet vi nok om pasientgruppen som ikke ønsker medisiner, hvorfor de ikke ønsker medikamentell behandling og hva som er viktigst for dem?

For det andre lurer jeg på om vi vet nok om hvordan dagens tilbud til dem som ikke ønsker medisiner, oppleves av pasientene? Røssberg og medforfattere skriver at tilbudet finnes innen dagens helsevesen, men mange brukere rapporterer at de ikke opplever tilbudet og valget som reelt. Derfor spør jeg meg også om vi vet nok om hvordan behandlingskulturer påvirker møtet med pasienter som ikke ønsker medisiner?

For det tredje ønsker jeg vi kan diskutere spørsmålet om autonomi. Det må sees i lys av dagens kunnskap om behandling av alvorlig psykisk lidelse. Jeg forsøkte å reise denne diskusjonen ved å trekke frem noe av kunnskapsgrunnlaget for gunstig effekt av antipsykotika, og tatt i betraktning dette, om man likevel kan forsvare behandlingsfrie tilbud. Jeg forsøkte altså å belyse at diskusjonen har en etisk side, som ikke har fått så stor plass i diskusjonen så langt.

For det fjerde lurer jeg på hva vi i helsevesenet bør gjøre for pasientene som ikke ønsker den behandlingen som anbefales, men som likevel lider. Det er en interessant diskusjon om man da skal vente med å igangsette tiltak inntil man har sikker dokumentert kunnskap, eller om man skal innføre et tiltak i samarbeid med brukerne, for deretter å undersøke systematisk om tiltaket har effekt. Hva tjener vi og hva taper vi på en slik strategi?

Etter min mening er diskusjonen best tjent med at man med akademisk nysgjerrighet utforsker hverandres argumenter.

\section{Ketil Slagstad}

ketil.slagstad@tidsskriftet.no

Ketil Slagstad (f. 1983) er medisinsk redaktør i Tidsskriftet. Ingen oppgitte interessekonflikter.

\section{Re: Psykiatriens indre konflikter eksponert}

Stiftelsen Humania avholdt 8.2.2017 en konferanse med tittelen «Hva er kunnskapsgrunnlaget for behandling med eller uten bruk av psykofarmaka?» (1). Både tilhengere og kritikeren Jan Ivar Røssberg av medisinfrie behandlingstilbud kom til orde, sammen med den internasjonalt kjente vitenskapsjournalisten Robert Whitaker (2). Han har nylig skrevet en reportasje fra den medisinfrie enheten ved Åsgård sykehus, under tittelen «The door to a revolution in psychiatry cracks open» (3). Her blir flere paradigmeskiftespørsmål satt på spissen.

Det er interessant å legge merke til at Norsk psykiatrisk forening så sent som i desember 2016 ikke hadde tatt stilling i saken, men besluttet å ha et «åpent sinn». I en artikkel om medisinfrie behandlingstilbud stilte daværende leder Anne Kristine Bergem blant annet følgende spørsmål (4) (vår oversettelse fra engelsk): Virker 